\title{
Alterations in Leaf Ultrastructure in Varieties of Sugarcane Infected by Diseases
}

\author{
Allan de Marcos Lapaz ${ }^{1}$, Lucas Aparecido Manzani Lisboa ${ }^{2}$, Ronaldo da Silva Viana ${ }^{2}$, Lucas Ferreira ${ }^{1}$, \\ Camila Hatsu Pereira Yoshida ${ }^{3}$, Jailson Vieira Aguilar ${ }^{1}$, Sérgio Bispo Ramos ${ }^{2}$, Valter Alves Pradela ${ }^{3}$, \\ Artur Bernardeli Nicolai ${ }^{2} \&$ Paulo Alexandre Monteiro de Figueiredo ${ }^{2}$ \\ ${ }^{1}$ Department Biology and Zootechnics, São Paulo State University, Brazil \\ ${ }^{2}$ Department of Technology and Agricutural Sciences, São Paulo State University, Brazil \\ ${ }^{3}$ University of Western São Paulo, Brazil \\ Correspondence: Allan de Marcos Lapaz, Department Biology and Zootechnics, São Paulo State University, \\ Brazil. E-mail: allanlapaz60@gmail.com
}

Received: April 24, 2019

doi:10.5539/jas.v11n11p223
Accepted: June 1, 2019 Online Published: July 31, 2019

URL: https://doi.org/10.5539/jas.v11n11p223

\begin{abstract}
Given the importance of viral, bacterial and fungal diseases in agriculture and their impact on crop yields, this study evaluated leaf ultrastructural changes in sugarcane varieties infected by these diseases, aiming to find morphological responses that may be associated to the decline of sugarcane yield. Three independent experiments were carried out with sugarcane varieties. In the three experiments, a randomised block design was used with 10 replications. The treatments consisted of the following diseases: mosaic from infection of variety SP86-155 by SCMV (experiment 1); stunting from infection with bacterium Leifsonia xyli subsp. xyli and smut from infection with fungus Sporisorium scitamineum (formally called Ustilago scitaminea) in the variety SP70-3370 (experiment 2); and scald from infection of variety SP78-5495 by bacterium Xanthomonas albilineans (experiment 3). The ultrastructural parameters were evaluated: mesophyll thickness, xylem diameter, phloem beam diameter, epidermal thickness of the adaxial face, epidermal thickness of the abaxial face, cuticle thickness of the adaxial face and cuticle thickness of the abaxial face. Healthy plants were controls for the three experiments. Sugarcane plants with mosaic, stunting, smut and scald diseases show deleterious changes in leaf ultrastructure.
\end{abstract}

Keywords: leaf morphology, Leifsonia xyli subsp. Xyli, Ustilago scitaminea, Xanthomonas albilineans

\section{Introduction}

With a harvested area of approximately 9.8 million hectares, Saccharum officinarum (sugarcane) is one of the main crops of Brazilian agribusiness (CONAB, 2016). Research in this sector aims to increase production and select forms that are more resistant to the challenges inherent in its cultivation. Diseases are a major concern, being responsible for a decline in sugarcane yield and economic loss (Legaz et al., 2006). Such extreme problems include diseases causing mosaics, stunting, smut and scald.

The potyvirus sugarcane mosaic virus (SCMV), the major viral disease causing mosaics in sugarcane require a lot of attention due to its wide impact (Huang \& $\mathrm{Li}, 2016$ ). The initial symptoms present as chlorotic points with subsequent linear distribution, being more commonly found in the base of the leaves. The symptoms evolve to elongated areas of the leaves, giving the configuration of a mosaic. Depending on the strain of virus and the variety of sugarcane cultivated, plant growth can be markedly reduced (Gonçalves et al., 2007), since sugarcane varieties vary in their level of resistance to SCMV (Li et al., 2014). Moreover, in highly susceptible varieties, streaks may occur in the culms, with shortening of the internodes, in addition to the symptoms described above (Gonçalves et al., 2007).

The most effective strategy of plant virus control is the use of resistant varieties (Li et al., 2018). However, there are still few varieties of sugarcane that exhibit resistance to SCMV (Urashima et al., 2017); consequently, research on genetic improvements against this pathogen has been promoted.

Stunting is caused by an invading xylem bacterium Leifsonia xyli subsp. xyli (Cia et al., 2018). This disease has a wide geographical distribution, impacting sugarcane production in several countries. Even so, it is considered the 
least treated disease in the field, due to its main symptoms in sugarcane being reduced height and diameter of the collar, which can easily be attributed to other factors (Su et al., 2016).

Smut is a fungal disease with a wide prevalence in sugarcane plantations ( $\mathrm{Su}$ et al., 2016), making it one of the most critical diseases for the sugarcane industry. It is caused by the pathogen Sporisorium scitamineum (formally called Ustilago scitaminea), which causes early germination of buds, narrowing of stems and black whips at the tips (Sundar et al., 2012).

Scald is caused by bacterium Xanthomonas albilineans, which also colonise the xylem (Li et al., 2018). This disease differs from the others mentioned above in that it is asymptomatic for months or even years, which leads to the distribution of contaminated material ( $\mathrm{Li}$ et al., 2018). In addition, it can be expressed in two ways: chronically, with increasing disease severity; or acutely, with a sudden onset and death of plants (Rott et al., 2017).

In view of their seriousness, this study evaluated leaf ultrastructural changes in sugarcane varieties infected by these diseases, aiming to find morphological responses that may be associated to the decline of sugarcane yield.

\section{Material and Methods}

\subsection{Experimental Site}

The experiment was carried out from September 2013 to September 2014 at the Faculty of Technology Professor Fernando de Amaral de Almeida Prado (FATEC), Araçatuba, SP, Brazil (21 ${ }^{\circ} 10^{\prime} 56.319^{\prime \prime} \mathrm{S}$ and 50 $26^{\circ} 58.385^{\prime \prime} \mathrm{W}$; on average $400 \mathrm{~m}$ above sea level).

\subsection{Experimental Design and Treatments}

Three independent experiments were carried out with sugarcane varieties susceptible to pathogens. In the three experiments, a randomised block design was used with 10 replications, composed of three biological replications The treatments consisted of the following diseases: mosaic from infection of variety SP86-155 by SCMV (experiment 1); stunting from infection with bacterium $L$. xyli subsp. xyli and smut from infection with fungus $S$. scitamineum in the variety SP70-3370 (experiment 2); and scald from infection of variety SP78-5495 by bacterium $X$. albilineans (experiment 3 ). Healthy plants were controls for the three experiments.

\subsection{Experimental Set-up and Execution}

Sugarcane minirrebolos (stem parts with buds) were planted in Ultisol (Santos et al., 2013), with the following chemical attributes: $\mathrm{pH}=4.5$, organic matter $=4.5 \mathrm{~g} \mathrm{~kg}^{-1}, \mathrm{P}=6.0 \mathrm{mg} \mathrm{kg}^{-1}, \mathrm{~K}=4.6$ mmolc kg${ }^{-1}, \mathrm{Ca}=10.0 \mathrm{mmolc}$ $\mathrm{kg}^{-1}, \mathrm{Mg}=4.0$ mmolc kg-1, $\mathrm{S}=7.0 \mathrm{mg} \mathrm{kg}^{-1}$; potential acidity of hydrogen and aluminium $(\mathrm{H}+\mathrm{Al})=18.0 \mathrm{mmolc}$

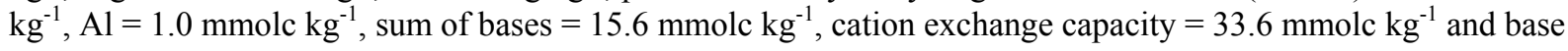
saturation $=46.4 \%$. The fertilization was according to regional recommendations of Raij et al. (1997).

The experimental unit consisted of four lines of sugarcane, each $5 \mathrm{~m}$ in length, with spacing of $1.5 \mathrm{~m}$ between lines. In each line, 14-17 minirrebolos were planted. For each experiment, plants in the two central lines and the three central metres were evaluated.

The pathogens used came from the Sugarcane Technological Center (CTC). The pathogens were isolated as described by Carollo and Santos Filho (2016); Fernandez (1993). The infection process was carried out at the time of planting, with solutions containing the pathogens being applied to the minirrebolos.

\subsection{Ultrastructure Parameters}

Leaf fragments were cut from the medial region of the limbus of leaf +1 (first leaf on the stalk from the top with visible dewlap) of the developed culm 300 days after the start of the experiment. They were fixed in $37 \%$ formaldehyde, acetic acid and 70\% ethanol at a ratio of 1.0:1.0:18.0, (v/v; F.A.A. 70 solution) for $48 \mathrm{~h}$. The leaf samples were then sent to the Laboratory of Plant Morphology and Forage Crops of the University of the State of São Paulo "Júlio de Mesquita Filho," located in the city of Dracena, State of São Paulo, Brazil.

Subsequently, the seedling tissue fragments were subjected to the following steps: dehydration, diaphanization, inclusion and fixation in paraffin, according to the methodology described by Kraus and Arduim (1997).

With the aid of a microtome table containing a steel blade, 8 - $\mu \mathrm{m}$ sections were cut from each embedded fragment. Each embedded fragment corresponds to an experimental plot. The sections of samples were fixed with Mayer adhesive, stained with $1 \%$ safranin and mounted on slides and coverslips with Entellan ${ }^{\circledR}$ adhesive (Kraus \& Arduim, 1997). 
The slides were observed under an Olympus ${ }^{\circledR}$ optical microscope model BX43 with a coupled camera to measure the ultrastructural parameters using the CellSens Standard ${ }^{\circledR}$ image analysis program, which was calibrated with a microscopic rule at the same zoom level as the photographs (Pereira et al., 2008).

In the midrib region of the leaves in the cross-sections, the following ultrastructural parameters were observed: mesophyll thickness, xylem diameter, phloem beam diameter, epidermal thickness of the adaxial face, epidermal thickness of the abaxial face, cuticle thickness of the adaxial face and cuticle thickness of the abaxial face (Carlquist, 1975). Each experimental plot was represented by the average of 10 measurements.

\subsection{Data Analysis}

The data were subjected to analysis of variance using the $\mathrm{F}$ test, at $\mathrm{p} \leq 0.05$. When significant, the parameters were submitted to the Tukey test $(\mathrm{p}<0.05)$. All statistical analysis of the data was performed using routines developed in the free software program R (R Core Team, 2018).

\section{Results}

\subsection{Sugarcane Infected With SCMV (Mosaic) (Experiment 1)}

When variety SP86-155 was infected with SCMV, a significant effect was found in the F-Test for the parameters mesophyll thickness and phloem beam diameter, with decreases in relation to controls of $12.04 \%$ and $15.63 \%$, respectively (Figures $1 \mathrm{~A}$ and $1 \mathrm{C}$ ).
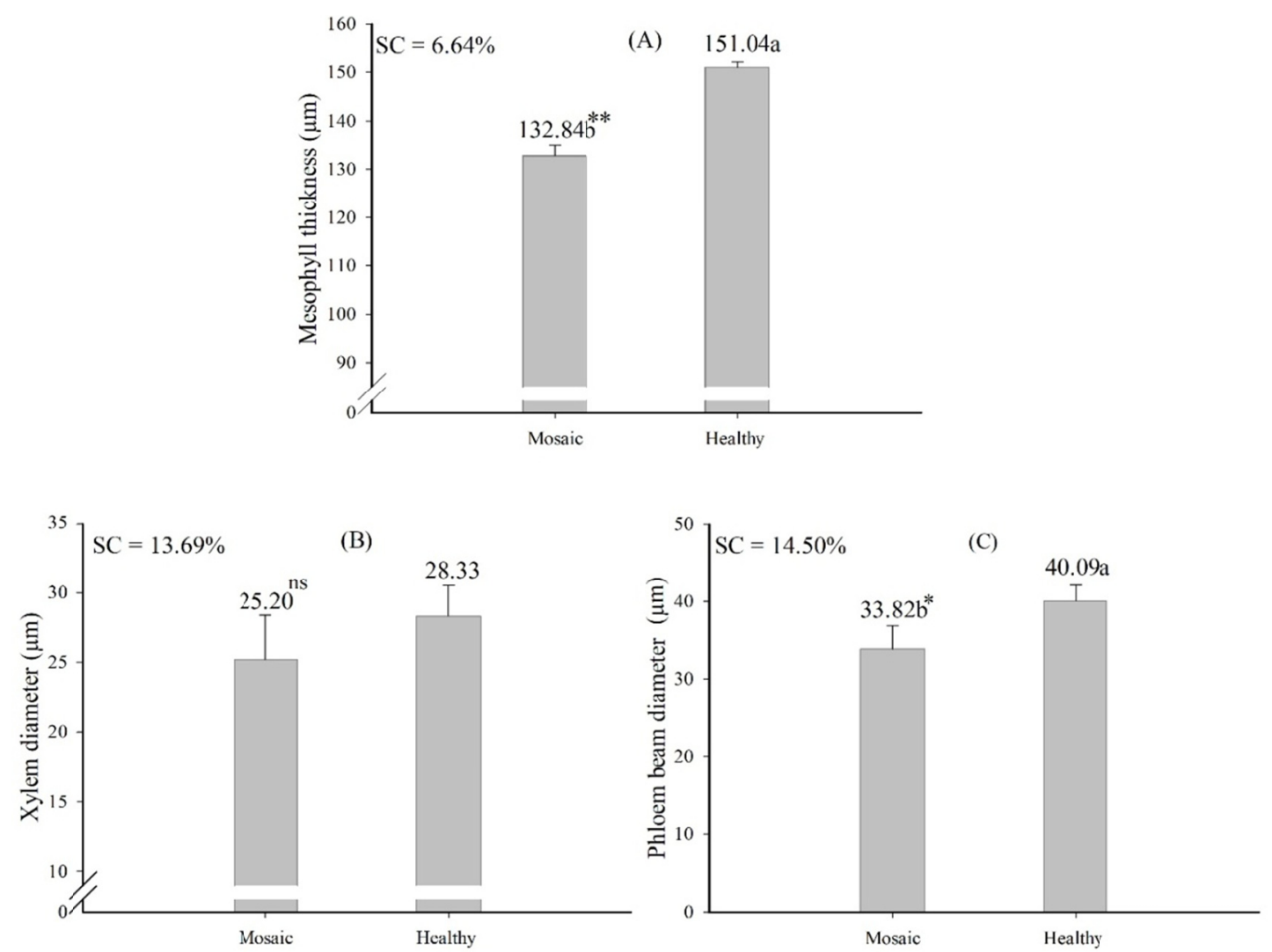

Figure 1. Mesophyll thickness (A), xylem diameter (B) and phloem beam diameter (C) for leaf tissue of sugarcane variety SP86-155 infected with SCMV (Mosaic), compared to that from control plants (Healthy). SC, standardised coefficient; ${ }^{\text {ns }}$, not significant; ${ }^{*}, \mathrm{p}<0.05 ;{ }^{* *}, \mathrm{p}<0.01 ;{ }^{* * *}, \mathrm{p}<0.001$; vertical bars represent the standard error

There was no statistical difference between treatments for other parameters, xylem diameter, epidermal thickness of the abaxial and adaxial face, and cuticle thickness of the abaxial and adaxial face (Figures 1B and 2A-2D). 

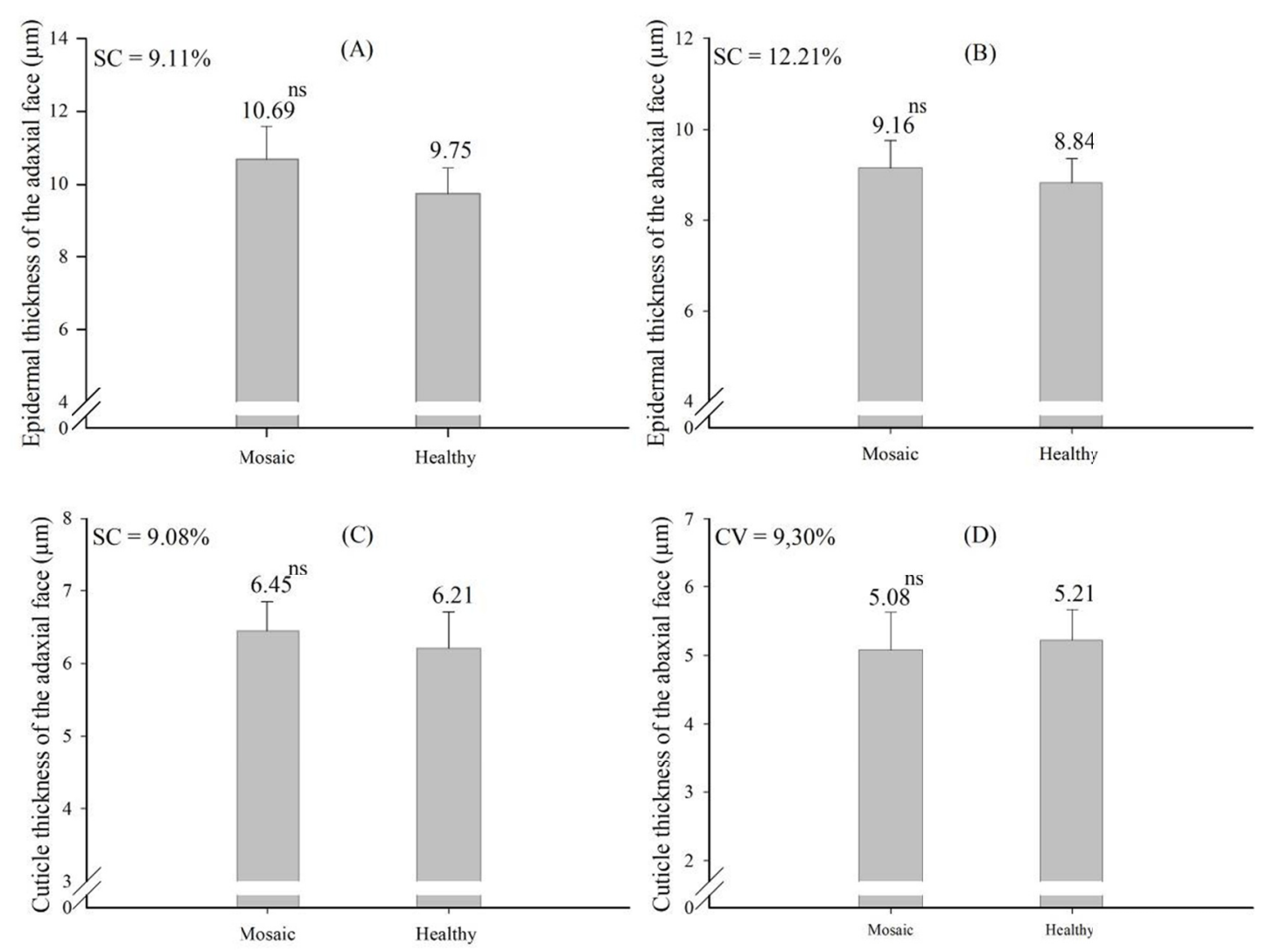

Figure 2. Epidermal thickness of the adaxial face (A), epidermal thickness of the abaxial face (B), cuticle thickness of the adaxial face (C) and cuticle thickness of the abaxial face (D) for leaf tissue of sugarcane variety SP86-155 infected with SCMV (Mosaic), compared to that from control plants (Healthy). SC, standardised coefficient; ${ }^{\text {ns }}$, not significant; ${ }^{*}, \mathrm{p}<0.05 ;{ }^{* *}, \mathrm{p}<0.01 ;{ }^{* * *}, \mathrm{p}<0.001$; vertical bars represent the standard error

\subsection{Sugarcane Infected With Leifsonia xyli subsp. xyli (Stunting) and Fungus Ustilago scitaminea (Smut) (Experiment 2)}

For infected plant tissue of variety SP70-3370, a significant effect was found in the F-test of parameters mesophyll thickness, xylem diameter, phloem beam diameter, epidermal thickness of the abaxial and adaxial face, and cuticle thickness of the abaxial face. However, the parameter cuticle thickness of the adaxial face did not show a statistical difference.

The mesophyll thickness was drastically affected when it was infected by $S$. scitamineum, showing a decrease of $24.65 \%$ in relation to the control. By comparison, when infected by $L . x y l i$ subsp. $x y l i$, the mesophyll thickness of sugarcane was not altered from that of the control treatment (Figure 3A).

Xylem diameter was of smaller calibre for both diseases relative to the controls, by $21.00 \%$ for stunting disease and $31.13 \%$ for smut disease (Figure 3B). The phloem beam diameter only showed a significantly lower calibre in relation to the control for smut disease, with a reduction of $20.48 \%$ (Figure $3 \mathrm{C}$ ). 

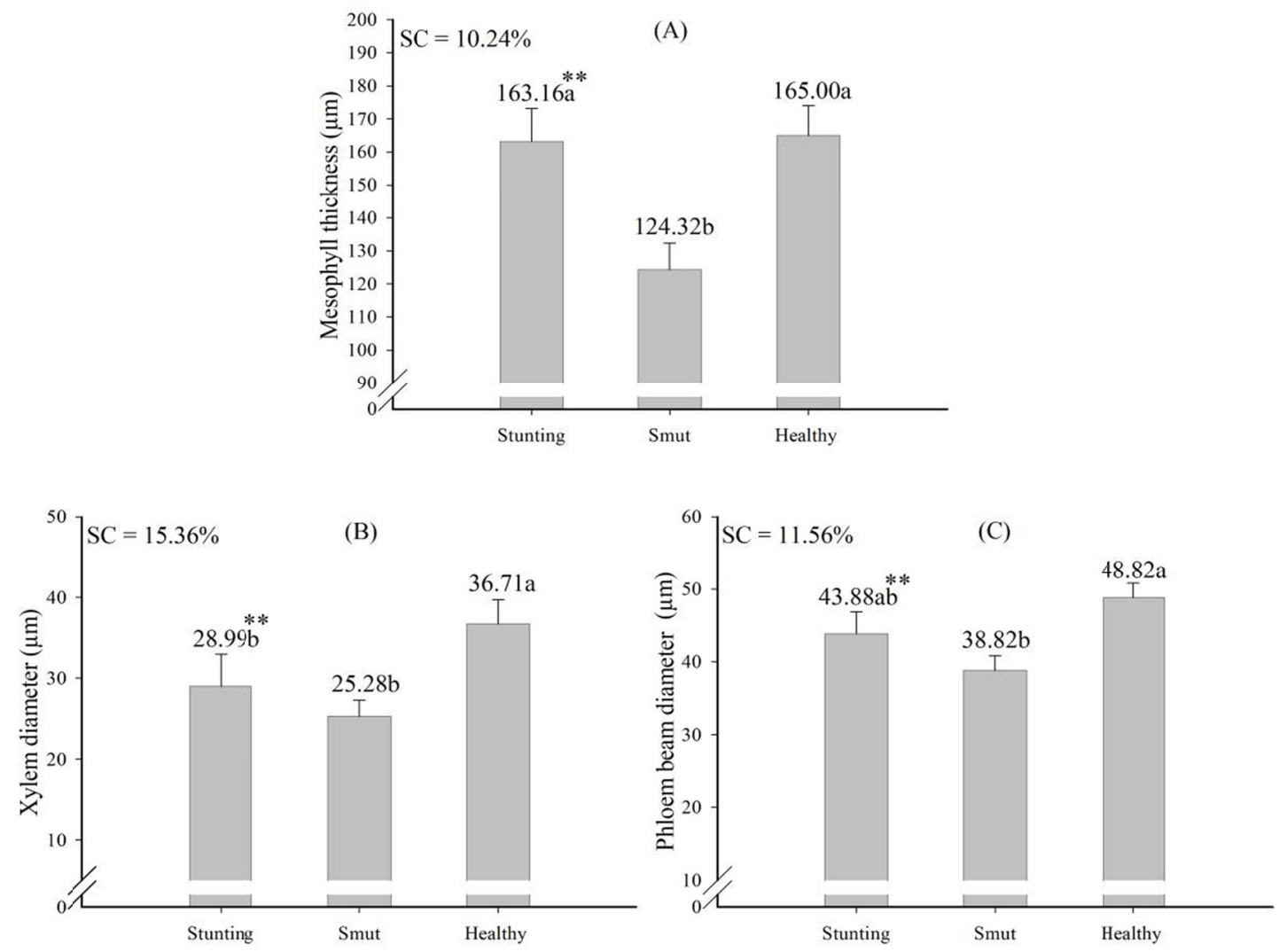

Figure 3. Mesophyll thickness (A), xylem diameter (B) and phloem beam diameter (C) for leaf tissue of sugarcane variety SP70-3370 infected with L. xyli subsp.xyli (Stunting) and fungus U. scitaminea (Smut), compared to that from control plants (Healthy). SC, Standardised coefficient; ${ }^{\text {ns }}$, not significant; ${ }^{*}, \mathrm{p}<0.05 ;{ }^{* *}, \mathrm{p}$ $<0.01 ;{ }^{* * *}, \mathrm{p}<0.001$; vertical bars represent the standard error

The thickness of the adaxial epidermis showed a marked decrease of $30.83 \%$ when infected by $U$. scitaminea. By comparison, it did not change for plants infected with L. xyli subsp. xyli from that observed in the control (Figure 4A). A similar pattern was found for epidermal thickness of the abaxial face, with a $26.7 \%$ decrease for smut disease compared to the control.

Cuticle thickness of the adaxial face showed values that did not differ from the control, with a mean value of $8.26 \mu \mathrm{m}$. By contrast, cuticle thickness of the abaxial face was altered by the two diseases, being inferior to the control by $21.62 \%$ for stuntingdisease and $31.45 \%$ for smut disease (Figure $4 \mathrm{D}$ ). 

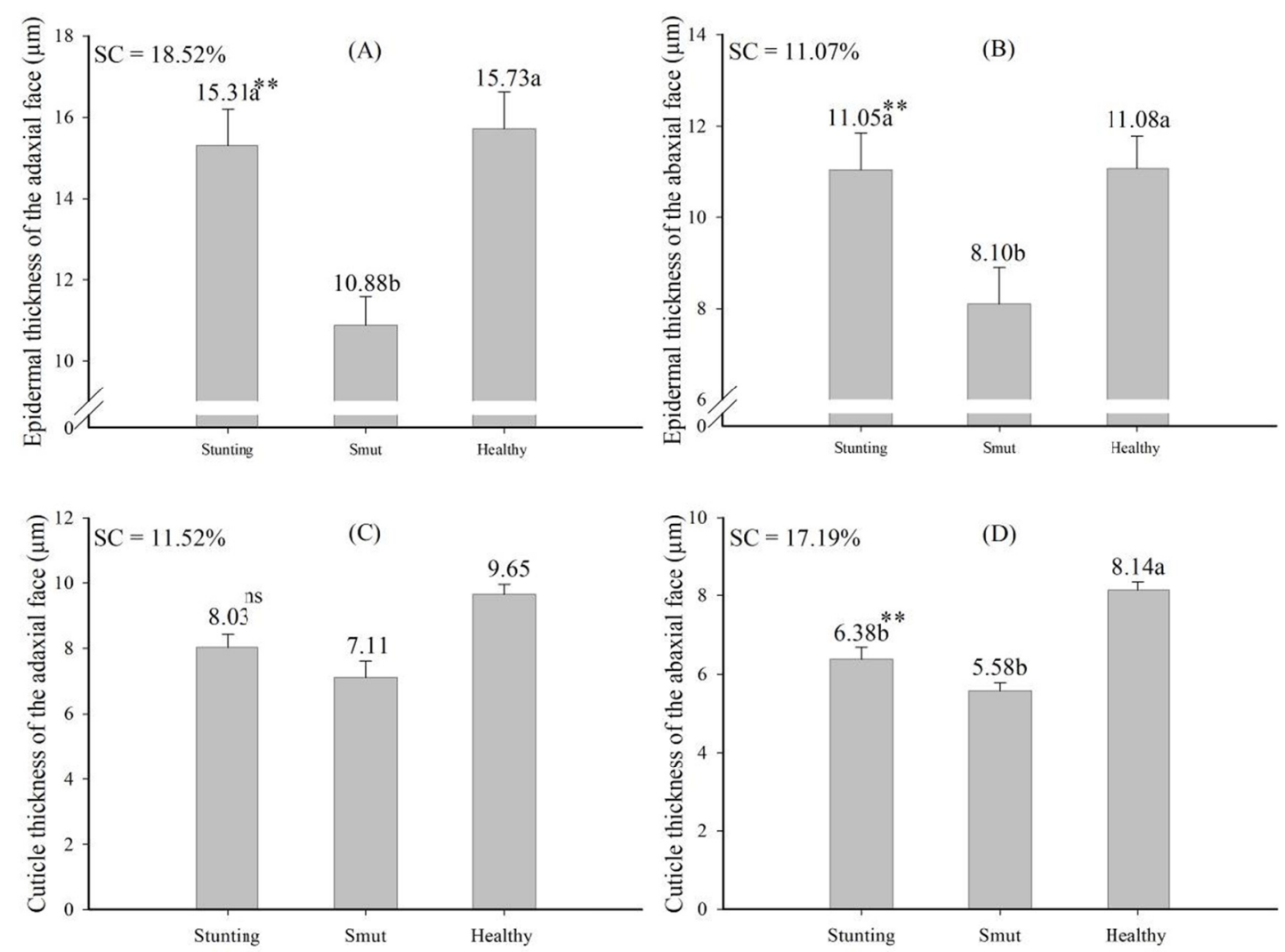

Figure 4. Epidermal thickness of the adaxial face (A), epidermal thickness of the abaxial face (B), cuticle thickness of the adaxial face $(C)$ and cuticle thickness of the abaxial face $(D)$ for leaf tissue of sugarcane variety SP70-3370 infected with L. xyli subsp. xyli (Stunting) and U. scitaminea (Smut), compared to that from control plants (Healthy). SC, standardised coefficient; ${ }^{\text {ns }}$, not significant; ${ }^{*}, \mathrm{p}<0.05 ;^{* *}, \mathrm{p}<0.01{ }^{* * *}, \mathrm{p}<0.001$; vertical bars represent the standard error

\subsection{Sugarcane Infected With Xanthomonas albilineans (Experiment 3)}

For plant tissue of variety SP78-5495 infected by X. albilineans, a significant effect was found in the F-test for parameters mesophyll thickness, xylem diameter, and phloem beam diameter, with decreases of 15.90, 19.29, and $15.27 \%$, respectively, in relation to the control (Figure 5). 

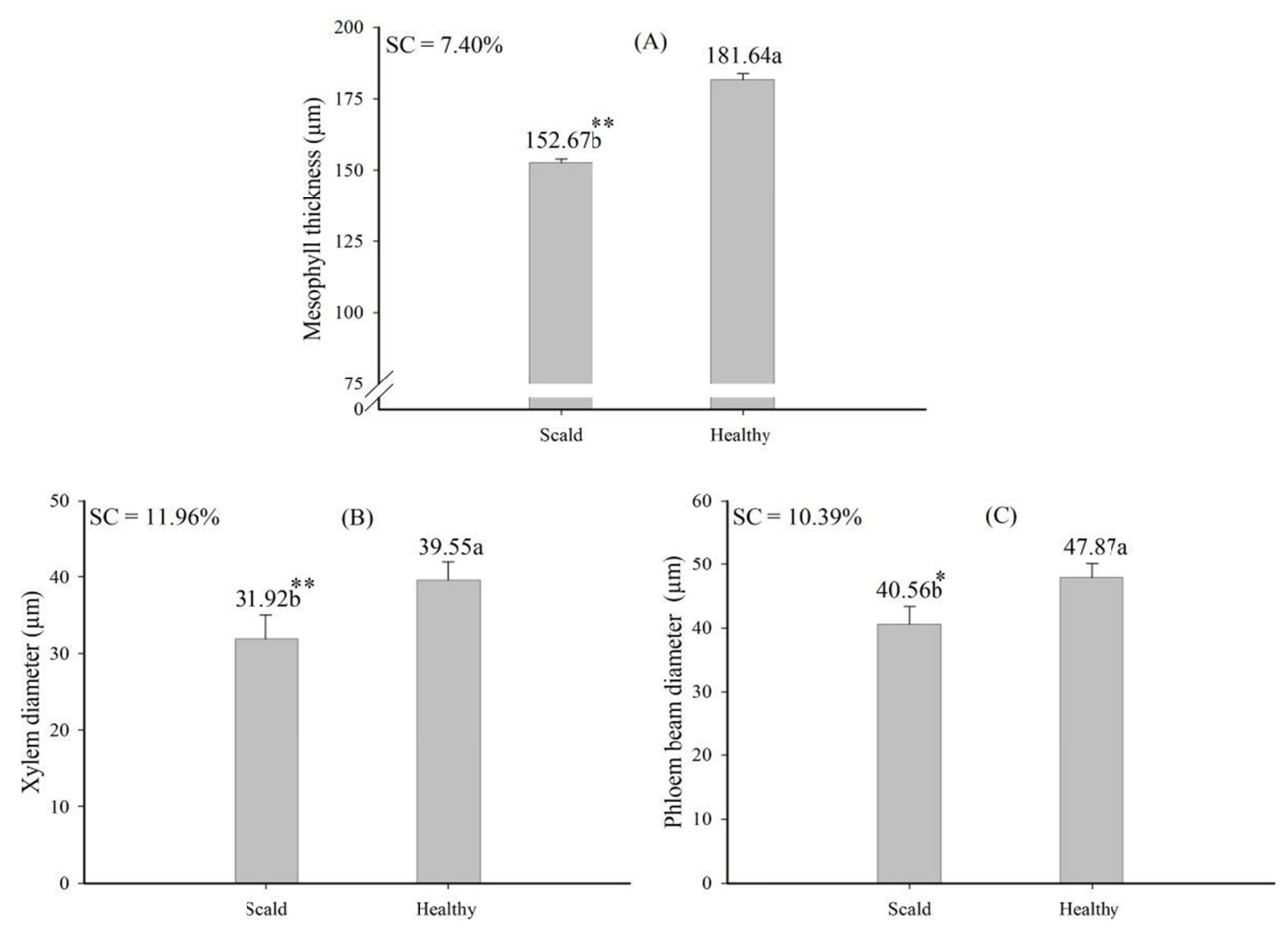

Figure 5. Mesophyll thickness (A), xylem diameter (B) and phloem beam diameter (C) for leaf tissue of sugarcane variety SP78-5495 infected with X. albilineans (Scald), compared to that from control plants (Healthy). SC, standardised coefficient; ${ }^{\text {ns }}$, not significant; ${ }^{*}, \mathrm{p}<0.05 ;{ }^{* *}, \mathrm{p}<0.01 ;{ }^{* * *}, \mathrm{p}<0.001$; vertical bars represent the standard error

The thickness of the adaxial epidermis of leaf tissue infected with $X$. albilineans showed a decrease of $12.22 \%$ (Figure 6A). By contrast, the thickness of the abaxial epidermis did not differ from the control, showing on average a value of $8.04 \mu \mathrm{m}$ (Figure 6B).

Cuticle thickness of the adaxial and abaxial faces did not differ from the control, having average values of $11.8 \mu \mathrm{m}$ and $6.06 \mu \mathrm{m}$, respectively (Figures $4 \mathrm{C}$ and $4 \mathrm{D}$ ). 

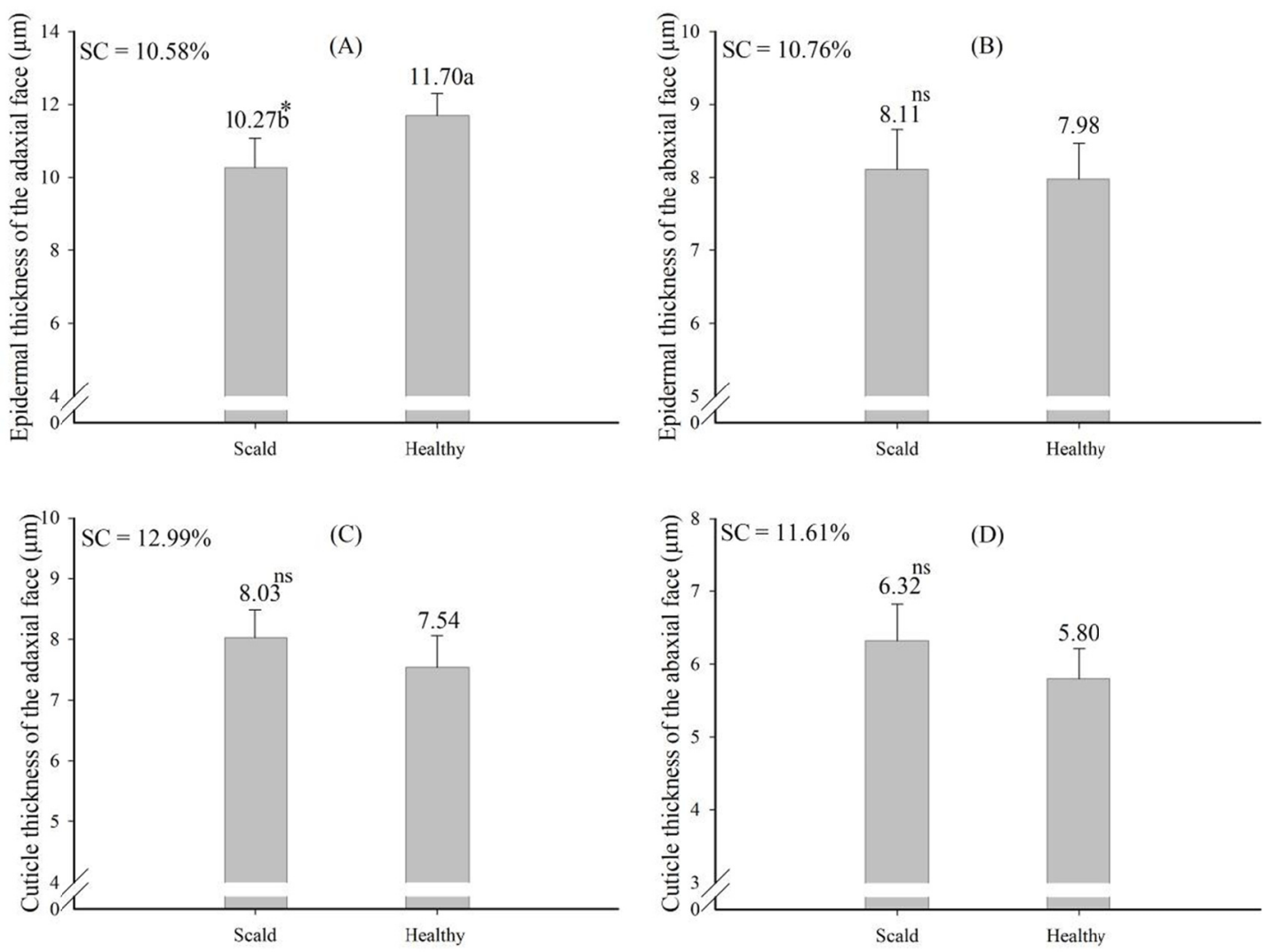

Figure 6. Epidermal thickness of the adaxial face (A), epidermal thickness of the abaxial face (B), cuticle thickness of the adaxial face (C) and cuticle thickness of the abaxial face (D) for leaf tissue of sugarcane variety SP78-5495 infected with $X$. albilineans (Scald), compared to that from control plants (Healthy). SC, standardised coefficient; ${ }^{\text {ns }}$, not significant; ${ }^{*}, \mathrm{p}<0.05 ;{ }^{* *}, \mathrm{p}<0.01 ;{ }^{* * *}, \mathrm{p}<0.001$; vertical bars represent the standard error

\section{Discussion}

Among the various tissues that compose the mesophyll, is the chlorophyllous parenchyma, cells with abundant amounts of chloroplasts and intercellular spaces responsible for photosynthesis, besides the presence of nutritive substances for plant metabolism (Figueiredo et al., 2014). Xylem is responsible for the upward transport of nutrients and water, conducting substances in the opposite direction to the phloem, which transports water, carbohydrates, amino acids, organic acids, proteins and nutrients to various destinations (Taiz \& Zeiger, 2013). The reduced thickness in conducting tissues of sugarcane infected with SCMV (Figure 1C), L. xyli subsp. xyli (Figure 3B), U. scitaminea (Figures 3B and 3C) and $X$. albilineans (Figures 5B and 5C) could influence the transport of xylem and phloem sap, possibly reducing the efficiency of these tissues (Figueiredo et al., 2013). In addition, the lower mesophyll thickness might interfere with the quantity or quality of substances produced in this area of the leaf (Figueiredo et al., 2014). In this respect, plant tissue infected with SCMV (Figure 1A), $U$. scitaminea (Figure 3A) and $X$. albilineans (Figure 5A) were most significantly affected.

Changes in the dimensions of the aforementioned parameters are extremely detrimental to crop yield (Figueiredo et al., 2013; Lisboa et al., 2018), which may explain the decrease in sugarcane yield observed by other authors for plants infected by the diseases used in the current study (Viswanathan \& Balamuralikrishnan, 2005; Bailey \& Bechet, 1995; Bruce, 2010; Rott et al., 1995).

Regarding the coating tissues, the epidermis has a primordial role for protecting plants against mechanical damage, such as herbivory, insect and pest attack, and phytopathogens (Castro et al., 2009; Stangarlin et al., 2011; Viana et al., 2015). Therefore, the epidermis exerts a protection function for the mesophyll, which is a photosynthetically active part of plants. As such, knowledge of their thickness becomes important in understanding the metabolic activity of plants (Figueiredo et al., 2014).

Smut disease resulted in a reduced thickness on both epidermis faces (Figures 2A and 2B), while scald disease affected only epidermal thickness on the adaxial face (Figure 6A). These changes could make plants infected by 
these diseases more susceptible to injury (Lapaz et al., 2017). Stunting and smut diseases caused changes in the cuticle thickness of the abaxial face, leaving it thinner (Figure 4D). Cuticles consist of lipid substances, such as wax and cutin. They function by reducing the diffusion of water vapor from the inner tissues of the leaf to the atmosphere. Thinner cuticles decrease the resistance to water loss from the leaf surface, and may reduce water use efficiency in these plants (Ferreira et al., 2015).

\section{Conclusion}

Sugarcane plants with mosaic, stunting, smut and scald diseases show deleterious changes in leaf ultrastructure.

\section{References}

Bailey, R. A., \& Bechet, G. R. (1995). The effect of ratoon stunting disease on the yield of some South African sugarcane varieties under irrigated and rainfed conditions. Proceedings of the South African Sugar Technologists'Association (pp. 74-78).

Bruce, R. C. (2010). Proceedings of the 2010 Conference of the Australian Society of Sugar Cane Technologists held at Bundaberg, Queensland, Australia, May 2010. Australian Society of Sugar Cane Technologists.

Carlquist, S. J. (1975). Ecological strategies of xylem evolution (p. 245). Berkeley, University of California Press.

Carollo, E. M., \& Santos Filho, H. P. (2016). Manual básico de técnicas fitopatológicas: laboratório de fitopatologia Embrapa Mandioca e Fruticultura. Embrapa Mandioca e Fruticultura-Folderes/Folhetos/ Cartilhas (INFOTECA-E).

Castro, E. D., Pereira, F. J., \& Paiva, R. (2009). Histologia vegetal: Estrutura e função de órgãos vegetativos (Vol. 9, No. 4). Lavras, UFLA.

Cia, M. C., Carvalho, G., Azevedo, R. A., Monteiro-Vitorello, C. B., Souza, G. M., Nishiyama-Junior, M. Y., ... Camargo, L. E. A. (2018). Novel insights into the early stages of ratoon stunting disease of sugarcane inferred from transcript and protein analysis. Phytopathology, 108(12), 1455-1466. https://doi.org/10.1094/ PHYTO-04-18-0120-R

Conab (Companhia Nacional de Abastecimento). (2016). Cana-de-açúcar: Primeiro Levantamento Abril, 2016. Retrieved from http://www.conab.com

Fernandez, M. R. (1993). Manual para laboratório de fitopatologia (p. 128). Passo Fundo: EMBRAPA/CNPT.

Ferreira, C. S., Carmo, W. S. D., Ribeiro, D. G., Oliveira, J. M. F. D., Melo, R. B. D., \& Franco, A. C. (2015). Anatomia da lâmina foliar de onze espécies lenhosas dominantes nas savanas de Roraima. Acta Amazonica, 45(4), 337-346. https://doi.org/10.1590/1809-4392201500363

Figueiredo, P. A. M., Ramos, S. B., Viana, R. S., Lisboa, L. A. M., \& Heinrichs, R. (2013). Alterações morfoanatômicas foliares da cana-de-açúcar na fase de estabelecimento em condições de matocompetição. Planta Daninha, 31(4), 777-84. https://doi.org/10.1590/S0100-83582013000400003

Figueiredo, P. A. M., Viana, R. S., Lisboa, L. A. M., Ramos, S. B., \& Machado, M. M. (2014). Características morfoanatômicas foliares de dois cultivares transgênicos de soja. Revista Mirante, 7(1), 111-120.

Gonçalves, M. C., Santos, A. S., Maia, I. D. G., Chagas, C. M., \& Harakava, R. (2007). Caracterização de um isolado do Sugarcane mosaic virus que quebra a resistência de variedades comerciais de cana-de-açúcar. Fitopatologia Brasileira, 32(1), 32-39. https://doi.org/10.1590/S0100-41582007000100004

Huang, Y. K., \& Li, W. F. (2016). Colored atlas of control on diseases, insect pests and weeds of modern sugarcane (pp. 118-121). Beijing: China Agriculture Press.

Kraus, J. E., \& Arduin, M. (1997). Manual básico de métodos em morfologia vegetal (Vol. 1, p. 198). Seropédica, Edur.

Lapaz, A. M., Santos, L. F. M., Yoshida, C. H. P., Figueiredo, P. A., Viana, R. S., \& Lisboa, L. M. (2017). Perda dos cotilédones em diferentes épocas no crescimento inicial do feijoeiro. Iheringia. Série Botânica, 72(2), 287-294. https://doi.org/10.21826/2446-8231201772216

Legaz, M. E., Millanes, A. M., Fontaniella, B., Piñon, D., De Armas, R., Rodríguez, C. W., Solas M. T., \& Vicente, C. (2006). Ultrastructural alterations of sugarcane leaves caused by common sugarcane pathogens. Belgian Journal of Botany, 136(1), 14-26.

Li, W. F., Shan, H. L., Zhang, R. Y., Wang, X. Y., Yang, K., Luo, Z. M., Cang J. L., \& Huang, Y. K. (2018). Identification of resistance to Sugarcane streak mosaic virus (SCSMV) and Sorghum mosaic virus (SrMV) 
in new elite sugarcane varieties/clones in China. Crop Protection, 110(8), 77-82. https://doi.org/10.1016/ j.cropro.2018.04.002

Li, W. F., Shen, K., Huang, Y. K., Wang, X. Y., Zhang, R. Y., Shan, H. L., ... Luo, Z. M. (2014). Evaluation of resistance to Sorghum Mosaic Virus (SrMV) in 49 new elite sugarcane varieties/clones in China. Crop Protection, 60(6), 62-65. https://doi.org/10.1016/j.cropro.2014.02.010

Lisboa, L. A. M., Lapaz, A. M., Bottan, A. P., Yoshida, C. H. P., Santos, L. F. M., Figueiredo, P. A. M., \& Viana, R. S. (2018) Ethephon action on germination and leaf ultrastruture of Urochloa brizantha cv. Marandu. Australian Journal of Basic and Applied Sciences, 12(4), 22-28.

Pereira, F. J., Castro, E. M., Souza, T. C., \& Magalhães, P. C. (2009). Evolução da anatomia radicular do milho'Saracura'em ciclos de seleção sucessivos. Pesquisa Agropecuária Brasileira, 43(12), 1649-1656. https://doi.org/10.1590/S0100-204X2008001200002

Raij, B. V., Cantarella, H., Quaggio, J. A., \& Furlani, A. M. C. (1997). Recomendações de adubação e calagem para o Estado de São Paulo (p. 286). Campinas, Instituto Agronômico/Fundação IAC.

Rott, P., Sandhu, H. S., Comstock, J. C., \& Gilbert, R. A. (2017). Sugarcane leaf scald disease. University of Florida IFAS Extension, SS-AGR-201.

Rott, P., Soupa, D., Brunet, Y., Feldmann, P., \& Letourmy, P. (1995). Leaf scald (Xanthomonas albilineans) incidence and its effect on yield in seven sugarcane cultivars in Guadeloupe. Plant Pathology, 44(6), 1075-1084. https://doi.org/10.1111/j.1365-3059.1995.tb02667.x

Santos, H. G., Jacomine, P. K. T., Anjos, L. H. C., Oliveira, V. A., Oliveira, J. B., Coelho, M. R., ... Cunha, T. J. F. (2013). Sistema brasileiro de classificação de solos (3rd ed., p. 353). Rio de Janeiro, Embrapa Solos.

Silva Viana, R., Figueiredo, P. A. M., Lisboa, L. A. M., \& Pascoaloto, I. M. (2015). Características morfoanatômicas de folhas de cana-de-açúcar sob efeito residual de maturadores. Revista Brasileira de Herbicidas, 14(4), 306-314. https://doi.org/10.7824/rbh.v14i4.438

Stangarlin, J. R., Kuhn, O. J., Toledo, M. V., Portz, R. L., \& Pascholati, S. F. (2011). A defesa vegetal contra fitopatógenos. Scientia Agraria Paranaensis, 10(1), 18-46.

Su, Y., Yang, Y., Peng, Q., Zhou, D., Chen, Y., Wang, Z., Xu, L., \& Que, Y. (2016). Development and application of a rapid and visual loop-mediated isothermal amplification for the detection of Sporisorium scitamineum in sugarcane. Scientific reports, 6, 23994. https://doi.org/10.1038/srep23994

Sundar, A. R., Barnabas, E. L., Malathi, P., \& Viswanathan, R. (2012). A mini-review on smut disease of sugarcane caused by Sporisorium scitamineum. In Botany. IntechOpen.

Taiz, L., \& Zeiger, E. (2013). Fisiologia vegetal (5th ed., p. 918). Porto Alegre, Artmed.

Team, R. C. (2018). R: A language and environment for statistical computing. R Foundation for Statistical Computing, Vienna, Austria.

Urashima, A. S., Silva, M. F., Correa, J. J., Moraes, M. C., Singh, A. V., Smith, E. C., \& Sainz, M. B. (2017). Prevalence and severity of ratoon stunt in commercial Brazilian sugarcane fields. Plant Disease, 101(5), 815-821. https://doi.org/10.1094/PDIS-07-16-1030-RE

Viswanathan, R., \& Balamuralikrishnan, M. (2005). Impact of mosaic infection on growth and yield of sugarcane. Sugar Tech, 7(1), 61-65. https://doi.org/10.1007/BF02942419

\section{Copyrights}

Copyright for this article is retained by the author(s), with first publication rights granted to the journal.

This is an open-access article distributed under the terms and conditions of the Creative Commons Attribution license (http://creativecommons.org/licenses/by/4.0/). 